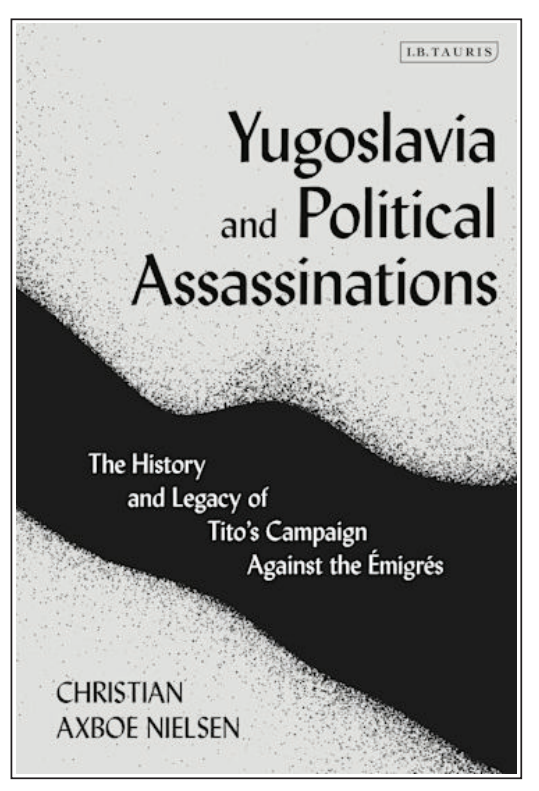

\title{
Yugoslavia and Political Assassinations: The History and Legacy of Tito's Campaign against the Émigrés
}

\author{
Christian Axboe Nielsen \\ London, New York: I. B. Tauris \\ 253 sider. ISBN 9781788315241 \\ Omtalt av Svein Mønnesland [professor emeritus, \\ Universitetet i Oslo, sveinmon@ilos.uio.no]
}

Under Tito hadde Jugoslavia et svært positivt image i utlandet. Siden Tito hadde trosset Stalin, innført en kommunisme med menneskelig ansikt og dessuten balanserte mellom øst og vest under den kalde krigen, var vestlige land villige til å lukke øynene for mer negative trekk ved regimet. Et aspekt som man nok ante, men visste lite om, var virksomheten til de jugoslaviske hemmelige tjenestene utenfor Jugoslavia. At jugoslaviske eksilorganisasjoner drev terrorvirksomhet, var kjent, men mindre kjent var det at jugoslaviske myndigheter likviderte sine fiender $\mathrm{i}$ utlandet.

Christian Axboe Nielsen har satt seg fore å undersøke hvordan Titos hemmelige tjenester opererte. Mye er skrevet om emnet etter kommunistpartiets fall, men ikke alle framstillinger er like pålitelige. I den senere tid har en del arkiver åpnet, men militære arkiver er fremdeles ikke tilgjengelige, heller ikke arkivene i Beograd. Forfatteren har derfor måttet foreta litt av et detektivarbeid for å samle inn det omfattende kildematerialet boken bygger på.

Jugoslavias politiske system var i stor grad desentralisert, og noe av utfordringen med å studere Titos hemmelige tjenester ligger i omfanget av dem. Etter 1974 var det, i tillegg til den føderale, åtte hemmelige tjenester i delrepublikkene og de to autonome områdene. Det var dessuten tretten ulike organer som opererte i utlandet, inkludert to militære etterretningstjenester og to som var underlagt utenriksdepartementet. Dessuten var de interne strukturene «bysantinske» i all sin kompleksitet. Tjenesten ble opprinnelig kalt Statens sikkerhetsadministrasjon, Uprava državne 
bezbednosti (UDBA), men dette ble senere endret til Statens sikkerhetstjeneste, Služba državne bezbednosti (SDB), på kroatisk Služba državne sigurnosti (SDS).

Det er fascinerende å få innblikk i SDBs håndbøker om hvordan agenter skulle opptre, for eksempel for å infiltrere antijugoslaviske organisasjoner. Overvåkingen av egne og utenlandske statsborgere var omfattende. Axboe Nielsen sannsynliggiør at likvideringer var hyppige og godkjent fra høyeste hold, altså av Tito selv. Det antydes at antall likvideringer oversteg hundre, men boken er ikke en katalog over alle kjente og mulige tilfeller av likvidering. Forfatteren er heller ikke primært opptatt av skyldspørsmål, men analyserer de hemmelige tjenestene som organisasjon. Han er historiker, ikke jurist.

SDB hadde som primæroppgave å beskytte kommunistpartiet og dets maktposisjon. Lignende organer finner man jo også i demokratiske stater, men som forfatteren sier: "The Yugoslav State Security existed to protect a one-party state, and it was this role as a guardian of dictatorship which ensured its highly repressive role» (s. 26).

Selv om det fantes ekstreme eksilgrupper fra ulike deler av Jugoslavia, var hovedfienden de kroatiske emigrantene. I 1945 flyktet mange i forbindelse med kommunistenes maktovertagelse, ikke bare fascister, men også motstandere av kommunismen. Mange ustasjamedlemmer slo seg ned i Argentina eller Spania. Den kroatiske diasporaen dannet organisasjoner og utga aviser. En ny bølge av kroatiske emigranter kom på slutten av 1960- og begynnelsen av 1970-tallet, mange flyttet til Vest-Tyskland, Østerrike og Australia. En del av disse var unge ekstremister som gikk inn for terror og sabotasjeaksjoner i Jugoslavia. I hele etterkrigstiden pågikk en krig mellom jugoslaviske myndigheter og ekstreme kroatiske emigranter. Forfatteren gir en god oversikt over de ulike kroatiske emigrantorganisasjonene og grupperingene.

Axboe Nielsens fortelling er spennende, ikke minst når han følger livet til noen av de mest prominente personene som ble likvidert, som Josip Senić og Vjekoslav «Maks» Luburić. Senić førte et omflakkende liv, fra Australia til Sverige, som en av lederne for Hrvatsko revolucionarno bratstvo (Det kroatiske revolusjonære brorskap), hele tiden fotfulgt av jugoslaviske hemmelige tjenester.

I stedet for likvidering ble det $\mathrm{i}$ enkelte tilfeller benyttet kidnapping til Jugoslavia. Slike hemmelige transporter over grenser var ikke enkle, men tjenestene hadde sine kanaler. Forfatteren går nøyere inn på ett slikt tilfelle, kidnappingen av den serbiske forretningsmannen Slobodan "Bata» Todorović, som ble bortført fra München til Ljubljana i 1975 og utsatt for lange og intense forhør før han fikk en dom på 20 år.

Et av de mest omtalte eksemplene på likvidering skiller seg fra de øvrige. Stjepan Djureković tilhørte ikke emigrantene, men hadde en ledende stilling i det kommunistiske Jugoslavia, som direktør i oljeselskapet INA. I 1982 forsvant han og dukket opp i Vest-Tyskland, hvor han begynte å utgi antijugoslaviske bøker og tidsskrifter, som ble trykt i en garasje i småbyen Wolfratshausen. Han hadde ambisjoner om å bli en leder for de kroatiske emigrantene. Femten måneder etter at han forsvant ble han likvidert i garasjen. Axboe Nielsen går nøye inn på Djureković-saken og 
sannsynliggjør at SDS sto bak, selv om rettssaken i Tyskland mot SDS-sjefene Josip Perković og Zdravko Mustač, som i 2016 fikk livstidsdommer, ikke frembrakte konkrete bevis.

Axboe Nielsen begrunner hvorfor mye har måttet utelates fra boken. Det er likevel underlig at den mest kjente politiske likvideringen begått i Skandinavia, attentatet mot Jugoslavias ambassadør i Sverige, Vladimir Rolović, i 1971, nesten ikke nevnes. Det er også lite om den i dag mest kjente personen som foretok likvideringer for de hemmelige jugoslaviske tjenestene i utlandet, Željko Ražnatović, bedre kjent som «Arkan». Selv om tema for boken er de hemmelige organisasjonenes oppbygning og virksomhet, blir leseren nysgjerrig og ønsker mer informasjon om enkelte operasjoner.

Vestlige land hadde et dilemma. På den ene side var de for ytringsfrihet og tillot antikommunistisk propaganda. På den annen side hadde de forståelse for Jugoslavias vanskelige posisjon mellom øst og vest og var imot eksiljugoslavenes terrorvirksomhet. De kunne derfor samarbeide med de jugoslaviske tjenestene og se gjennom fingrene med overgrep i egne land. Forfatteren mener at særlig sosialdemokratene i Tyskland hadde en tendens til å overse Jugoslavias ulovlige virksomhet. Det hadde vært interessant å få utdypet vestlige politikeres holdninger til disse operasjonene.

Etter oppløsningen av Jugoslavia skjedde noe overraskende i Kroatia. Den tidligere kommunistiske hemmelige tjenesten i Kroatia ble en del av det nye kroatiske etablissementet, med den tidligere omtalte Perković i spissen. Samtidig vendte mange av de ekstreme kroatiske nasjonalistene som hadde operert i eksil hjem, og noen fikk ledende stillinger. Tidligere fiender samarbeidet dermed under president Franjo Tuđman! Ifølge forfatteren lever det i Kroatia den dag i dag en konspirasjonsteori om at UDBA/SDB er skyld i alt ondt, samtidig som Perković og andre ikke fordømmes. Axboe Nielsen kunne ha nevnt at kroatiske emigranter som begikk terroraksjoner, i dag hylles som helter. Dette gjelder for eksempel Miro Barišić, medskyldig i mordet på ambassadør Rolović.

Boken er et viktig bidrag til moderne jugoslavisk historie. Den bygger på nitide arkivstudier, er logisk bygd opp, og gir et innblikk i hvordan en stat kan operere mot sine fiender. Jugoslavia finnes ikke lenger, men det kan være andre stater som i dag bruker lignende metoder. 